九州大学学術情報リポジトリ

Kyushu University Institutional Repository

\title{
Post-bisulfite adaptor tagging for PCR-free whole-genome bisulfite sequencing
}

Miura, Fumihito

Department of Biochemistry, Graduate School of Medical Sciences, Kyushu University

Ito, Takashi

Department of Biochemistry, Graduate School of Medical Sciences, Kyushu University

http://hdl. handle. net/2324/4151257

出版情報: Methods in Molecular Biology. 1708, pp.123-136, 2017-12-10. Humana Press バージョン：

権利関係 : 
Post-bisulfite adaptor tagging for PCR-free whole-genome bisulfite sequencing

Fumihito Miura ${ }^{1,2,3}$ and Takashi Ito ${ }^{1,2}$

${ }^{1}$ Department of Biochemistry, Kyushu University Graduate School of Medical Sciences, 3-1-

1 Maidashi, Higashi-ku, Fukuoka 812-8582, Japan,

${ }^{2}$ Core Research for Evolutional Science and Technology (CREST), Japan Agency for Medical

Research and Development (AMED), 3-1-1 Maidashi, Higashi-ku, Fukuoka 812-8582, Japan

${ }^{3}$ Precursory Research for Embryonic Science and Technology (PRESTO), Japan Science and

Technology Agency (JST), 3-1-1 Maidashi, Higashi-ku, Fukuoka 812-8582, Japan

Corresponding author: Takashi Ito, tito@med.kyushu-u.ac.jp 


\section{Summary}

Post-bisulfite adaptor tagging (PBAT) is a highly efficient procedure to construct libraries for whole-genome bisulfite sequencing (WGBS). PBAT attaches adaptors to bisulfite-converted genomic DNA to circumvent bisulfite-induced degradation of library DNA inherent to conventional WGBS protocols. Consequently, it enables PCR-free WGBS from nanogram quantities of mammalian DNA, thereby serving as an invaluable tool for methylomics.

Key words: Methylome, Next generation sequencing, PCR-free, Single-nucleotide resolution

Running Head: PBAT: post-bisulfite adaptor tagging 


\section{Introduction}

The current gold standard for single-base resolution methylome analysis is whole-genome bisulfite sequencing (WGBS). WGBS was first applied to the Arabidopsis methylome [1,2] and then applied to a variety of organisms. While its power is remarkable, it has a practical drawback in terms of the amount of input DNA: it typically requires a few micrograms of DNA (i.e., approximately a million mammalian diploid cells). This number of cells is difficult or sometimes even prohibitive for various biologically interesting samples, such as mammalian oocytes, early embryonic tissues, and tissue stem cells. Extensive PCR amplification to compensate limitation of input DNA not only exacerbates biased genomic representation, but makes the estimate of methylation level inaccurate. This is due to the bisulfite conversion that induces sequences differences in the methylated and unmethylated alleles of the same locus leading to differential amplification.

To expand the range of samples suitable for WGBS, a novel protocol that requires a much smaller amount of input DNA than the conventional ones is required. Although bisulfite treatment induces DNA fragmentation, the conventional as well as tagmentationbased protocols [3] (see also Chapter 5) include the step for bisulfite-treatment of adaptortagged DNAs that results in the degradation and low yield of DNA for the generation of the library (Fig. 1A). To circumvent this adverse effect, we conceived a novel principle termed Post-Bisulfite Adaptor Tagging (PBAT), in which adaptor tagging follows bisulfite 
treatment, in contrast to the other protocols [4] (Fig. 1B). Since it is difficult to efficiently ligate adaptors to bisulfite-treated, denatured DNAs, we developed a simple adaptortagging protocol using two rounds of random primer extension (Fig. 1C).

The random priming-based PBAT protocol can generate a PCR-free library from as little as 125 pg of DNA. It typically allows generating a WGBS library of sufficient quality and diversity to achieve $\sim 30$-fold, PCR-free coverage of the mammalian genomes from $\sim 30$ ng of DNA. We and others have successfully applied PBAT to various samples ranging from plants, fungi and animals, especially those with limited amounts of DNA (see also Chapter 8). For instance, PBAT has realized PCR-free, mouse WGBS from only 1,000 oocytes and a few thousand flow-sorted primordial germ cells $[5,6]$. We have also applied PBAT to targetenriched genomic DNA, thereby achieving a highly efficient targeted methylome sequencing [7]. In contrast to conventional PCR-assisted WGBS, PBAT can preferentially cover GC-rich genic regions and CpG islands. We expect that the PBAT protocol described below will help readers conduct various novel WGBS applications.

\section{Materials}

\subsection{Reagents}

1. Qubit dsDNA BR Assay Kit.

2. Qubit dsDNA HS Assay Kit. 
3. Qubit ssDNA Assay Kit.

4. Agencourt AMPure XP beads.

5. 10x PCR buffer: $100 \mathrm{mM}$ Tris- $\mathrm{HCl}, 500 \mathrm{mM} \mathrm{KCl}, 15 \mathrm{mM} \mathrm{MgCl}$. $\mathrm{pH} 8.3$.

6. RNA 6000 Pico Kit (Agilent).

7. High Sensitivity DNA Kit (Agilent).

8. $10 \mathrm{mM}$ Tris-Hacetate, $\mathrm{pH}$ 8.0.

9. $\quad 10 \mathrm{mM}$ Tris-HCl, $\mathrm{pH}$ 7.5.

10. Klenow fragment $\left(3^{\prime} \rightarrow 5^{\prime}\right.$ exo-): high concentration $(50,000$ units $/ \mathrm{ml})(\mathrm{New}$ England Biolabs, NEB, see Note 1).

11. Bst DNA polymerase large fragment $(80,000 \mathrm{units} / \mathrm{ml})$ (NEB).

12. Exonuclease I (20,000 units/ml).

13. Phusion Hot Start II High-Fidelity DNA Polymerase (2 units/ $\mu \mathrm{l})$.

14. EZ DNA Methylation-Gold Kit (ZYMO Research).

15. Dynabeads M-280 Streptavidin.

16. 2x BW solution: dissolve $6.3 \mathrm{~g} \mathrm{LiCl}$ in $40 \mathrm{ml}$ of double-distilled water ( $\mathrm{ddH}_{2} \mathrm{O}$ ), after $\mathrm{LiCl}$ has completely dissolved, add $0.5 \mathrm{ml}$ of $1 \mathrm{M}$ Tris- $\mathrm{HCl}, \mathrm{pH}$ 8.0 and $0.1 \mathrm{ml}$ of $0.5 \mathrm{M}$ EDTA, and adjust the volume to $50 \mathrm{ml}$ with $\mathrm{ddH}_{2} \mathrm{O}$ (see Note 2).

17. $\quad 0.1 \mathrm{M} \mathrm{NaOH}$ (see Note 3). 
18. KAPA Library Quantification Kit for Illumina (KAPA Biosystems).

19. Hybridization Buffer A: combine $9 \mathrm{ml}$ of $5 \mathrm{M} \mathrm{NaCl}$ and $9 \mathrm{ml}$ of $1 \mathrm{M}$ Tris- $\mathrm{HCl}$, $\mathrm{pH} 7.4$, and bring to a final volume of $50 \mathrm{ml}$ with $\mathrm{ddH}_{2} \mathrm{O}$.

\subsection{Oligonucleotides}

1. Bio-PEA2-N4: $100 \mu \mathrm{M}$

5'-biotin-ACA CTC TTT CCC TAC ACG ACG CTC TTC CGA TCT NNN N-3'.

2. PE-reverse-N4: $100 \mu \mathrm{M}$

5'-CAA GCA GAA GAC GGC ATA CGA GAT NNN N-3'.

3. PBAT-PE-iX-N4: $100 \mu \mathrm{M}$ each

5'-CAA GCA GAA GAC GGC ATA CGA GAT XXXX XXX GTA AAA CGA CGG CCA GCA GGA AAC AGC TAT GAC NNN N-3'.

Replace the underlined hexamer with one of the following index sequences, which are complementary to those used in the Illumina's TruSeq DNA LT Sample Prep Kit, so that the same index numbers as those in the kit can be used.

The index numbers 17, 24 and 26 are reserved by Illumina for unknown reasons.

\begin{tabular}{l|l|ll||ll} 
Index \# & Sequence & Index \# & Sequence & Index \# & Sequence \\
1 & CGTGAT & 9 & CTGATC & 18 & GCGGAC \\
2 & ACATCG & 10 & AAGCTA & 19 & TTTCAC
\end{tabular}




\begin{tabular}{|c|c|c|c|c|c|}
\hline 3 & GCCTAA & |11 & GTAGCC & 20 & GGCCAC \\
\hline 4 & TGGTCA & 12 & TACAAG & 21 & CGAAAC \\
\hline 5 & CACTGT & 13 & TTGACT & 22 & CGTACG \\
\hline 6 & ATTGGC & 14 & GGAACT & 23 & ССАСТС \\
\hline 7 & GATCTG & 15 & TGACAT & 25 & ATCAGT \\
\hline 8 & TCAAGT & 16 & GGACGG & 27 & AGGAAT \\
\hline
\end{tabular}

4. Primer 3: $100 \mu \mathrm{M}$ :

5'-AAT GAT ACG GCG ACC ACC GAG ATC TAC ACT CTT TCC CTA CAC

GAC GCT CTT CCG ATC T-3'.

5. PBAT-PE-Seq:

5'-GTA AAA CGA CGG CCA GCA GGA AAC AGC TAT GAC-3'.

6. PBAT-PE-Idx:

5'-GTC ATA GCT GTT TCC TGC TGG CCG TCG TTT TAC-3'.

\subsection{Plastic disposables}

1. Microcentrifuge and PCR tubes: In all the steps, use of low-retention 1.5 and $0.2 \mathrm{ml}$ tubes is recommended.

2. Pippette tips: use of low-retention tips is recommended for dispensing streptavidin-coated magnetic beads. 


\subsection{Equipment}

1. DynaMag-2 Magnet (LifeTechnologies, or equivalent).

2. SPRIPlate 96R Magnet Plate (Beckman Coulter, or equivalent).

3. High-speed refrigerated microcentrifuge.

4. Agilent Bioanalyzer 2100.

5. Qubit Fluorometer or Qubit 2.0 Fluorometer.

6. TOMY PMC-060 Capsulefuge (or equivalent).

7. Thermal cycler.

8. StepOnePlus Real-Time PCR System (Applied Biosystems or equivalent).

\section{Methods}

\subsection{Bisulfite Treatment (Day 1)}

1. Measure the concentration of the DNA sample with the Qubit dsDNA BR Assay Kit and Qubit Fluorometer according to the manufacturer's instructions (see Note 4).

2. Add $900 \mu \mathrm{l}$ of $\mathrm{ddH}_{2} \mathrm{O}, 50 \mu \mathrm{l}$ of $\mathrm{M}$-Dissolving Buffer, and $300 \mu \mathrm{l}$ of M-Dilution Buffer to one tube of CT Conversion Reagent from the EZ DNA MethylationGold Kit. Dissolve the material by rotating the tube of CT Conversion Reagent for $10 \mathrm{~min}$. at room temperature. 
3. Mix the following components well: $130 \mu \mathrm{l}$ of CT conversion reagent, $(20-\mathrm{x})$ $\mu \mathrm{ddH_{2 }}$, and $x \mu l$ of sample DNA (see Notes 5, 6).

4. Divide the solution into three $50 \mu \mathrm{l}$ aliquots in $0.2 \mathrm{ml}$ tubes.

5. Place the tubes on a thermal cycler, and start the following program: $98^{\circ} \mathrm{C}$ for $10 \mathrm{~min}$., $64^{\circ} \mathrm{C}$ for $150 \mathrm{~min}$., followed by hold at at $4^{\circ} \mathrm{C}$.

6. Place a Zymo-Spin IC Column in a Collection Tube and add $600 \mu \mathrm{l}$ of MBinding Buffer to the column.

7. Add the sample from Step 5 to the M-Binding Buffer in the column. Close the cap and mix by inverting several times.

8. Centrifuge at full speed $(\geq 10,000 \times g)$ for $30 \mathrm{~s}$.

9. Reload the flow-through onto the same column again (see Note 7).

10. Centrifuge at full speed $(\geq 10,000 \times g)$ for $30 \mathrm{~s}$. Discard the flow-through

11. Add $100 \mu \mathrm{l}$ of M-Wash Buffer prepared with ethanol to the column, and centrifuge at full speed for $30 \mathrm{~s}$. Discard the flow-through.

12. Add $200 \mu \mathrm{l}$ of M-Desulphonation Buffer to the column and let the column stand at room temperature for $15 \mathrm{~min}$.

13. Centrifuge at full speed for $30 \mathrm{~s}$. Discard the flow-through.

14. Add $200 \mu \mathrm{l}$ of M-Wash Buffer with ethanol to the column and centrifuge at full speed for $30 \mathrm{~s}$. Discard the flow-through. 
15. Repeat the wash in Step 14 one more time and then transfer the spin column to a new clean $1.5 \mathrm{ml}$ tube.

16. Add $22 \mu \mathrm{l}$ of M-Elution Buffer directly to the column matrix and let the column stand at room temperature for $2 \mathrm{~min}$. Centrifuge at full speed for $30 \mathrm{~s}$ to elute the DNA (see Notes 8, 9).

\subsection{First-strand synthesis (Day 1)}

1. Prepare the first-strand synthesis reaction mix as follows: Add $5 \mu$ l of 10x NEB Buffer 2, $5 \mu \mathrm{l}$ of $2.5 \mathrm{mM}$ dNTPs, $16 \mu \mathrm{l}$ of $\mathrm{ddH}_{2} \mathrm{O}, 4 \mu \mathrm{l}$ of $100 \mu \mathrm{M}$ primer BioPEA2-N4 and $20 \mu \mathrm{l}$ of bisulfite-treated sample DNA from Section 3.1.

2. Place the tube on a thermal cycler and start the following program: $94^{\circ} \mathrm{C}$ for 5 min., $4^{\circ} \mathrm{C}$ for $20 \mathrm{~min}$. , gradual increase from $4^{\circ} \mathrm{C}$ to $37^{\circ} \mathrm{C}$ at a rate of $+1^{\circ} \mathrm{C} / \mathrm{min}$., $37^{\circ} \mathrm{C}$ for $90 \mathrm{~min} ., 70^{\circ} \mathrm{C}$ for $10 \mathrm{~min}$., followed by hold at at $4^{\circ} \mathrm{C}$ (see Note 10 ).

3. After $5 \mathrm{~min}$. of incubation at $4^{\circ} \mathrm{C}$ (i.e., the second step of the program), pause the program and remove the tube from the thermal cycler. Add $1.5 \mu$ of Klenow fragment $\left(3^{\prime} \rightarrow 5^{\prime} \mathrm{exo}^{-}\right)$to the first-strand synthesis mix and mix well.

4. Place the tube on the thermal cycler again and resume the program to complete the first-strand synthesis reaction (see Note 11). 


\subsection{Removal of Excess Primers (Day 2)}

1. Transfer the solution of the first-strand reaction $(\sim 50 \mu \mathrm{l})$ into a new $1.5 \mathrm{ml}$ tube, add $50 \mu \mathrm{l}$ of AMPure XP beads, mix well, and spin the tube briefly (see Note 12).

2. Let the tube stand at room temperature for $10 \mathrm{~min}$.

3. Place the tube on a magnetic stand and wait for the beads to be collected. Then, remove the supernatant carefully and make sure not to aspirate the beads.

4. Add $200 \mu \mathrm{l}$ of $75 \%$ ethanol to wash the beads and then remove the supernatant.

5. Add $45 \mu \mathrm{l}$ of $10 \mathrm{mM}$ Tris-HAcetate buffer and vortex the tube well to suspend the beads. After a brief centrifugation, place the tube on the magnetic stand and wait for the beads to be collected.

6. Transfer the supernatant into a new $1.5 \mathrm{ml}$ tube. Add $5 \mu \mathrm{l}$ of 10x PCR Buffer and $50 \mu \mathrm{l}$ of AMPure XP beads to the supernatant. Then mix well and spin briefly (see Note 13).

7. Let the tube stand at room temperature for $10 \mathrm{~min}$.

8. Place the tube on the magnetic stand and wait for the beads to be collected. Then remove the supernatant carefully not to aspirate the beads. 
9. Add $200 \mu \mathrm{l}$ of $75 \%$ ethanol to wash the beads and then remove the supernatant.

10. Add $51 \mu \mathrm{l}$ of $10 \mathrm{mM}$ Tris-HAcetate buffer and vortex the tube well to suspend the beads. After a brief centrifugation, place the tube on the magnetic stand and wait for the beads to be collected.

11. Transfer the supernatant in a new $1.5 \mathrm{ml}$ tube.

12. Use $1 \mu \mathrm{l}$ of the supernatant to measure the DNA concentration using the Qubit dsDNA HS kit (see Note 14).

\subsection{Capturing Biotinylated DNA on Streptavidin Beads (Day 2)}

1. Take $20 \mu \mathrm{l}$ of well-dispersed suspension of Dynabeads M280 Streptavidin beads into a $1.5 \mathrm{ml}$ tube. Place the tube on a magnet stand to collect the beads.

2. Remove the supernatant, and add $50 \mu \mathrm{l}$ of $2 \times \mathrm{BW}$ buffer to suspend the beads.

3. Add the suspension of beads to the product obtained in Section 3.3.

4. Incubate the tube at room temperature for $30 \mathrm{~min}$. while gently rotating the tube.

5. Place the tube on the magnet stand to collect the beads and then remove the supernatant. 
6. Add $180 \mu \mathrm{l}$ of $2 x$ BW buffer to the beads, vortex well, and spin the tube briefly.

7. Place the tube on the magnet stand to collect the beads and then remove the supernatant.

8. Suspend the beads in $180 \mu \mathrm{l}$ of $0.1 \mathrm{M} \mathrm{NaOH}$, vortex well, incubate at room temperature for 2 min., and spin briefly.

9. Place the tube on the magnet stand to collect the beads and then remove the supernatant.

10. Repeat steps 8 and 9.

11. Add $180 \mu \mathrm{l}$ of $2 x$ BW buffer to the beads, vortex well, and spin the tube briefly.

12. Place the tube on the magnet stand to collect the beads and then remove the supernatant.

13. Add $180 \mu \mathrm{l}$ of $10 \mathrm{mM}$ Tris- $\mathrm{HCl}$ to the beads, vortex well, and spin the tube briefly.

\subsection{Second-strand Synthesis (Day 2)}

1. Place the tube on a magnet stand to collect the beads and remove the supernatant. 
2. Prepare the second-strand synthesis reaction mix as follows and add to the beads: $5 \mu \mathrm{l}$ of 10x NEB Buffer 2, $5 \mu \mathrm{l}$ of $2.5 \mathrm{mM}$ dNTPs, $36 \mu \mathrm{l}$ of $\mathrm{ddH}_{2} \mathrm{O}, 4 \mu \mathrm{l}$ of $100 \mu \mathrm{M}$ PE-reverse-N4, for single-end sequencing, or PBAT-PE-iX-N4 for paired-end and index sequencing.

3. Suspend the beads by vortexing, and transfer the beads suspension into a new $0.2 \mathrm{ml}$ tube.

4. Place the tube on a thermal cycler and start the following program: $94^{\circ} \mathrm{C}$ for 5 min., $4^{\circ} \mathrm{C}$ for $20 \mathrm{~min}$. gradual increase from $4^{\circ} \mathrm{C}$ to $37^{\circ} \mathrm{C}$ at a rate of $+1^{\circ} \mathrm{C} / \mathrm{min}$., $37^{\circ} \mathrm{C}$ for $30 \mathrm{~min} ., 70^{\circ} \mathrm{C}$ for $10 \mathrm{~min}$., followed by hold at at $4^{\circ} \mathrm{C}$ (see Note 10 ).

5. After $5 \mathrm{~min}$. of the incubation at $4^{\circ} \mathrm{C}$ (i.e., the second step of the program), pause the program and remove the tube from the thermal cycler. Add $1.5 \mu \mathrm{l}$ of Klenow Fragment $\left(3^{\prime} \rightarrow 5^{\prime} \mathrm{exo}^{-}\right)$to the second-strand synthesis solution and mix well.

6. Place the tube on the thermal cycler again and resume the program to complete the second-strand synthesis reaction.

\subsection{Chase reaction (Day 2)}

1. Place the tube on a magnet stand to collect the beads and remove the supernatant. 
2. Prepare the chase reaction mix as follows and add to the beads: $5 \mu$ lof $10 x$

ThermoPol Buffer (provided with the Bst polymerase large fragment), $5 \mu \mathrm{l}$ of $2.5 \mathrm{mM}$ dNTPs, $40 \mu \mathrm{l}$ of $\mathrm{ddH}_{2} \mathrm{O}$ and $1 \mu \mathrm{l}$ of Bst DNA polymerase large fragment.

3. Incubate the reaction mix at $65^{\circ} \mathrm{C}$ for $30 \mathrm{~min}$.

\subsection{Elution/extension of Template DNA (Day 2) (see Note 15)}

1. Place the tube on a magnet stand to collect the beads and remove the supernatant.

2. Prepare the elution/extension reaction mix as follows and add to the beads: 10 $\mu \mathrm{l}$ 5x Phusion HS buffer, $5 \mu \mathrm{l}$ of $2.5 \mathrm{mM}$ dNTPs, $35 \mu \mathrm{l}$ of $\mathrm{ddH}_{2} \mathrm{O}, 0.4 \mu \mathrm{l}$ of 100 $\mu \mathrm{M}$ Primer 3 and $1 \mu \mathrm{l}$ of Phusion Hot Start High-fidelity DNA polymerase

3. Start the following program: $94^{\circ} \mathrm{C}$ for $5 \mathrm{~min} ., 55^{\circ} \mathrm{C}$ for $15 \mathrm{~min} ., 68^{\circ} \mathrm{C}$ for 30 min., followed by hold at at $4^{\circ} \mathrm{C}$.

4. Place the tube on the magnet stand to collect the beads, and transfer the supernatant into a new $1.5 \mathrm{ml}$ tube.

5. Add $1 \mu \mathrm{l}$ of exonuclease I to the supernatant, mix well, and incubate the tube at $37^{\circ} \mathrm{C}$ for $30 \mathrm{~min}$. followed by heat inactivation at $70^{\circ} \mathrm{C}$ for $10 \mathrm{~min}$. 
6. Use $1 \mu \mathrm{l}$ of eluted DNA with the Qubit dsDNA HS Kit to measure the concentration of DNA.

\subsection{Size fractionation (Day 2)}

1. Add $50 \mu \mathrm{l}$ of AMPure XP beads to the eluted DNA (50 $\mu \mathrm{l})$, mix well, and spin briefly.

2. Place the tube on a magnetic stand and wait for the beads to be separated.

Then, remove the supernatant carefully not to aspirate the beads.

3. Add $200 \mu \mathrm{l}$ of $75 \%$ ethanol to wash the beads and then remove the supernatant.

4. Add $45 \mu \mathrm{l}$ of $10 \mathrm{mM}$ Tris-HAcetate buffer and vortex the tube well to suspend the beads. After a brief centrifugation, place the tube on the magnetic stand and wait for the beads to be collected.

5. Transfer the supernatant to a new $1.5 \mathrm{ml}$ tube.

6. Add $5 \mu \mathrm{l}$ of 10x PCR Buffer and $50 \mu \mathrm{l}$ of AMPure XP beads to the supernatant. Mix well and spin briefly.

7. Let the tube stand at room temperature for $10 \mathrm{~min}$.

8. Place the tube on the magnetic stand and wait for the beads to be collected. Then, remove the supernatant carefully not to aspirate the beads. 
9. Add $200 \mu \mathrm{l}$ of $75 \%$ ethanol to wash the beads, and then remove the supernatant.

10. Add $22 \mu \mathrm{l}$ of $10 \mathrm{mM}$ Tris-HAcetate buffer and vortex well to disperse the beads. After a brief centrifugation, place the tube on the magnetic stand and wait for the beads to be collected.

11. Transfer the supernatant to a new $1.5 \mathrm{ml}$ tube.

12. Use $1 \mu \mathrm{l}$ of the supernatant to measure the concentration of DNA using the Qubit dsDNA HS kit (see Note 16).

13. Subsequently, determine the exact molar concentration of template DNA using an appropriate qPCR assay (see Note 17).

\subsection{Illumina sequencing}

Here, we provide guidance about sequencing PBAT libraries on Illumina HiSeq2000, HiSeq2500 and MiSeq instruments.

\subsubsection{Calculation of template volume required for sequencing}

1. Calculate the volume of template required in cluster generation using the following equation and parameters (see Note 18). 


\begin{tabular}{|c|c|c|c|}
\hline Platform & HiSeq 2000 & $\begin{array}{l}\text { HiSeq } 2500 \text { in } \\
\text { rapid mode } \\
\text { with cBot }\end{array}$ & $\begin{array}{l}\text { HiSeq } 2500 \text { in } \\
\text { rapid mode } \\
\text { without cBot } \\
\text { or MiSeq }\end{array}$ \\
\hline $\begin{array}{l}\text { Target concentration of } \\
\text { denatured template }(\mathrm{pM})\end{array}$ & $10^{*}$ & $10^{*}$ & $10^{*}$ \\
\hline Target volume of template $(\mu \mathrm{l})$ & 120 & 70 & 480 \\
\hline $\begin{array}{l}\text { Molar concentration of } \\
\text { template }(\mathrm{pM})\end{array}$ & $\mathrm{Y}$ & $\mathrm{Y}$ & $\mathrm{Y}$ \\
\hline $\begin{array}{l}\text { Volume of template required }= \\
x(\mu \mathrm{l})\end{array}$ & $\frac{120 \times 10}{y}$ & $\frac{70 \times 10}{y}$ & $\frac{480 \times 10}{y}$ \\
\hline
\end{tabular}

${ }^{*}$ For target concentration, $10 \mathrm{pM}$ is a good point to start optimization.

\subsubsection{Running a Single Lane of Illumina HiSeq2000}

1. Dispense $100 \mu \mathrm{l}$ plus extra volume of hybridization buffer A to a new $1.5 \mathrm{ml}$ tube and place it on ice.

2. Prepare a $2 \mathrm{M} \mathrm{NaOH}$ by diluting a $10 \mathrm{M} \mathrm{NaOH}$ solution.

3. Denature sequencing templates by combining $x \mu l$ of template DNA solution, $(19-x) \mu l$ of $d_{d d H_{2}} \mathrm{O}$ and $1 \mu l$ of $2 \mathrm{M} \mathrm{NaOH}$. 
4. Let the tube stand at room temperature for $5 \mathrm{~min}$.

5. Add $100 \mu \mathrm{l}$ of the ice-cooled hybridization buffer A to the denatured template, mix well, and place the tube on ice.

6. Start cluster generation according to the manufacturer's instructions (see Note 19).

\subsubsection{Running a Single Lane of Illumina HiSeq2500 in Rapid Mode with cBot}

1. Dispense $58 \mu \mathrm{l}$ plus extra volume of hybridization buffer A to a new $1.5 \mathrm{ml}$ tube and place it on ice.

2. Prepare a $2 \mathrm{M} \mathrm{NaOH}$ by diluting a $10 \mathrm{~m} \mathrm{NaOH}$ solution.

3. Denature sequencing templates by combining $x \mu l$ of template DNA solution, $(11-x) \mu l$ of $\mathrm{ddH}_{2} \mathrm{O}$ and $0.6 \mu \mathrm{l}$ of $2 \mathrm{M} \mathrm{NaOH}$.

4. Let the tube stand at room temperature for $5 \mathrm{~min}$.

5. Add $58 \mu$ l of the ice-cooled hybridization buffer A to the denatured template, mix well, and place the tube on ice.

6. Add $70 \mu \mathrm{l}$ of ice-cold $8 \mathrm{pM}$ denatured phiX control to the tube and mix well (see Note 20).

7. Start cluster generation according to the manufacturer's instruction. 


\subsubsection{Running a Single Lane of Illumina HiSeq2500 in Rapid Mode Without cBot or}

\section{Illumina MiSeq}

1. Dispense $400 \mu \mathrm{l}$ plus extra volume of hybridization buffer A to a new $1.5 \mathrm{ml}$ tube and put it on ice.

2. Prepare a $2 \mathrm{M} \mathrm{NaOH}$ by diluting a $10 \mathrm{M} \mathrm{NaOH}$ solution.

3. Denature sequencing templates by combining $x \mu l$ of template DNA solution, $(76-x) \mu l$ of $\mathrm{ddH}_{2} \mathrm{O}$ and $4 \mu \mathrm{l}$ of $2 \mathrm{M} \mathrm{NaOH}$.

4. Let the tube stand at room temperature for $5 \mathrm{~min}$.

5. Add $400 \mu \mathrm{l}$ of the ice-cold hybridization buffer A, mix well, and place the tube on ice.

6. Add $120 \mu \mathrm{L}$ of ice-cold $8 \mathrm{pM}$ denatured phiX control to the tube and mix well (see Note 20).

7. Start run according to the manufacturer's instruction (see Note 21).

\section{Notes}

1. Be sure to use high concentration enzymes (i.e., 50,000 U/ml).

2. Dissolving $\mathrm{LiCl}$ is an exothermic process. To avoid bumping of the solution, dissolve $\mathrm{LiCl}$ in $40 \mathrm{ml}$ of $\mathrm{ddH}_{2} \mathrm{O}$ once completely. Then, add Tris and EDTA, and adjust the volume to $50 \mathrm{ml}$ with $\mathrm{ddH}_{2} \mathrm{O}$. 
3. Dilute from $10 \mathrm{M} \mathrm{NaOH}$ stock before use.

4. Accurate estimation of DNA concentration is critical. We routinely use the Qubit dsDNA BR Assay Kit for the purpose. Avoid measuring at an optical density of $260 \mathrm{~nm}$, because various materials other than DNA absorb light at $260 \mathrm{~nm}$ and often result in an overestimation of DNA concentration. The size of input DNA seems to be less critical, as it does not affect the yield of library (Fig 2).

5. We routinely start with $100 \mathrm{ng}$ of DNA, because this amount is easy to handle. However, note that the maximum efficiency of template preparation is achieved with $\sim 1$ ng of DNA as a starting material. Thus, the bisulfite-treated DNA may be divided into several aliquots before first-strand synthesis to further increase the efficiency of template preparation. All reagents used in this step are provided in EZ DNA methylation kit.

6. Use freshly prepared CT conversion reagent to ensure high yield and efficient bisulfite conversion.

7. Because we occasionally encountered "shunts" in the column through which the solution flows to have minimal contact with the resin, the column should be carefully inspected before use. Reloading of the flow-through increases the contact of the solution with the resin. 
8. The elution volume $(22 \mu \mathrm{l})$ includes $1 \mu \mathrm{l}$ for determination of yield by the Qubit ssDNA Assay kit and $1 \mu \mathrm{l}$ for QC with the Agilent Bioanalyzer using the RNA 6000 Pico Kit. Typically, the yield of DNA is between 30\% and 70\% of the input. The typical size range of denatured DNA is 100 1,000 nt with a peak around $600 \mathrm{nt}$ (Fig 3). When the starting amount of DNA is $<30 \mathrm{ng}$, both platforms will fail to detect the eluted DNA. Thus, omit these QC steps and reduce the elution volume in Step 17 to $20 \mu \mathrm{l}$.

9. Do not stop here. Proceed immediately to the first-strand synthesis step, because the bisulfite-treated DNA is labile.

10. If your thermal cycler cannot generate a temperature ramp of $+1^{\circ} \mathrm{C} / \mathrm{min}$, you may use a two-step PCR cycling program with an increment of temperature by $1^{\circ} \mathrm{C}$ for every step. If the first cycle of the program is set as $4.0^{\circ} \mathrm{C}$ for $30 \mathrm{sec}$ followed by $4.5^{\circ} \mathrm{C}$ for $30 \mathrm{sec}$, then the temperature will reach to $37^{\circ} \mathrm{C}$ after 33 cycles with the intended rate of $+1^{\circ} \mathrm{C} / \mathrm{min}$.

11. You can stop here either by leaving the tube at $4^{\circ} \mathrm{C}$ or storing it at $-20^{\circ} \mathrm{C}$ until use. This is presumably because the bisulfite-treated DNAs are now doublestranded and excessive primers in the solution serve as a carrier DNA to prevent the adsorption of template DNA to the tube wall. 
12. At this mixing ratio (i.e., DNA solution:AMPure XP of 1:1), DNA fragments less than $200 \mathrm{bp}$ are effectively removed in the supernatant. While primers and primer dimers are less than $100 \mathrm{nt}$, the products of the first-strand synthesis are larger than $200 \mathrm{bp}$.

13. Addition of 10x PCR Buffer at this step increases the reproducibility and yield of AMPure XP-based purification of DNA.

14. Typical yields at this step are between $40 \%$ and $60 \%$ of the input. When the starting amount of DNA is $<30 \mathrm{ng}$, the kit will fail to quantify the DNA. Thus, omit this QC step and reduce the elution volume in Step 10 to $50 \mu \mathrm{l}$.

15. This step not only enables the precise selection of double-stranded DNA by SPRI beads, but also synthesizes the sequence required for bridge PCR.

16. Typical yield at this step is between $20 \%$ and $40 \%$ of the input DNA. When the starting amount of DNA is $<30 \mathrm{ng}$, the kit will fail to quantify DNA. Thus, omit this QC step and reduce the elution volume in Step 9 to $21 \mu 1$.

17. Note that the product obtained in Section 3.8 contains not only intact sequencing templates but also several-fold greater amounts of by-products. Thus, it is essential to determine the correct concentration of the template DNA by qPCR but not by fluorometry. We perform quantification using Library Quantification Kits for Illumina (KAPA biosystems) according to the 
manufacturer's instruction, because it is easy to use and highly reproducible. Typical mass yield at this step is calculated to be $2 \sim 8 \%$ relative to the starting amount of DNA. If the starting DNA is $100 \mathrm{ng}$, this number corresponds to $\sim 20 \mathrm{fmol}$ of template, which is sufficient for 20 lanes or 4 runs of sequencing on a Illumina HiSeq 2000 or MiSeq, respectively. In addition, the by-products make it impossible to examine the size of template DNA directly by electrophoresis. Accordingly, we analyze the size of qPCR product. Because the size distribution of PCR-amplified templates becomes unreliable after the PCR reaches the plateau, we run the amplified product ona $6 \%$ polyacrylamide/7M urea gel in TBE buffer ( $89 \mathrm{mM}$ Tris, $89 \mathrm{mM}$ boric acid, 2 mM EDTA). As shown in Fig 4, the typical size is between $200 \mathrm{bp}$ and $500 \mathrm{bp}$ with a peak around $300 \mathrm{bp}$.

18. Be sure to add PBAT-PE-Seq and PBAT-PE-Idx to the Illumina primer mix at the final concentration of $0.5 \mu \mathrm{M}$ each for paired-end and index sequencing.

19. Since bisulfite-converted DNA has an extremely biased base composition, each flow cell must include a control lane for the phiX control template to enable correct normalization of fluorescent signals. 
20. For the same reason as described in Note $\mathbf{1 9}$, the phiX control template must be added to the sample. Follow the instruction provided by Illumina for the preparation of denatured phiX control template.

21. We usually use 101 cycles for sequencing. The reads are adequately processed and used for mapping. While a number of bisulfite mappers have been made available, it often happens that unique characteristics of PBAT reads not only necessitates appropriate preprocessing of the data but hampers their efficient mapping. We recommend a popular bisulfite mapper, bismark, which has an option "pbat" (http://www.bioinformatics.babraham.ac.uk/projects/bismark/). We also provide BMap that uses an algorithm termed adaptive seeds for highly efficient mapping of PBAT reads (http://itolab.med.kyushuu.ac.jp/BMap/).

\section{Ackowledgements}

This work was supported by Research Program of Innovative Cell Biology by Innovative Technology (Cell Innovation) of the Ministry of Education, Culture, Sports, Science and Technology (MEXT) and the Platform Project for Supporting in Drug Discovery and Life Science Research (Platform for Drug Discovery, Informatics and Structural Life Science) of AMED. 


\section{References}

1. Cokus SJ, Feng S, Zhang X et al (2008) Shotgun bisulphite sequencing of the Arabidopsis genome reveals DNA methylation patterning. Nature 452: 215219.

2. Lister R, O'Malley RC, Tonti-Filippini J et al (2008) Highly integrated singlebase resolution maps of the epigenome in Arabidopsis. Cell 133:523-536.

3. Adey A, Shendure J (2012) Ultra-low-input, tagmentation-based wholegenome bisulfite sequencing. Genome Res 22:1139-1143.

4. Miura F, Enomoto Y, Dairiki R et al (2012) Amplification-free whole-genome bisulfite sequencing by post-bisulfite adaptor tagging. Nucleic Acids Res 40:e136.

5. Shirane K, Toh H, Kobayashi H et al (2013) Mouse oocyte methylomes at base resolution reveal genome-wide accumulation of non-CpG methylation and role of DNA methyltransferases. PLoS Genet 9:e1003439.

6. Kobayashi H, Sakurai T, Miura F et al (2013) High-resolution DNA methylome analysis of primordial germ cells identifies gender-specific reprogramming in mice. Genome Res 23:616-627. 
7. Miura T, Ito F (2015) Highly sensitive targeted methylome analysis by postbisulfite adaptor tagging. DNA Res 22:13-18. 


\section{Figure Legends}

Fig. 1. Principle of PBAT. (A) Conventional WGBS protocols. Bisulfite treatment follows adaptor-tagging and degrades adaptor-tagged library DNAs. (B) PBAT strategy. Adaptortagging follows bisulfite treatment to circumvent bisulfite-induced fragmentation of adaptor-tagged library DNAs. (C) Random priming-mediated PBAT. Two rounds of random primer extension on bisulfite-converted genomic DNA generate directionally adaptor-tagged library DNAs.

Fig. 2. Effect of input DNA size. (A) Agarose gel electrophoresis of DNAs variously fragmented using the Covaris S220 acoustic sonicator. (B) Yields of libraries generated from $100 \mathrm{ng}$ of the variously fragmented DNA shown in (A).

Fig. 3. Typical size distribution of bisulfite-treated DNA. Bisulfite-treated genomic DNA was separated on an Agilent Bioanalyzer 2100 using the RNA 6000 pico kit.

Fig. 4. Typical size distribution of sequencing templates. Amplification products of $\mathrm{qPCR}$ to quantify libraries generated from the indicated amount of input DNA were separated on 6\% Novex TBE-Urea gel and stained with SYBR Gold. 
A
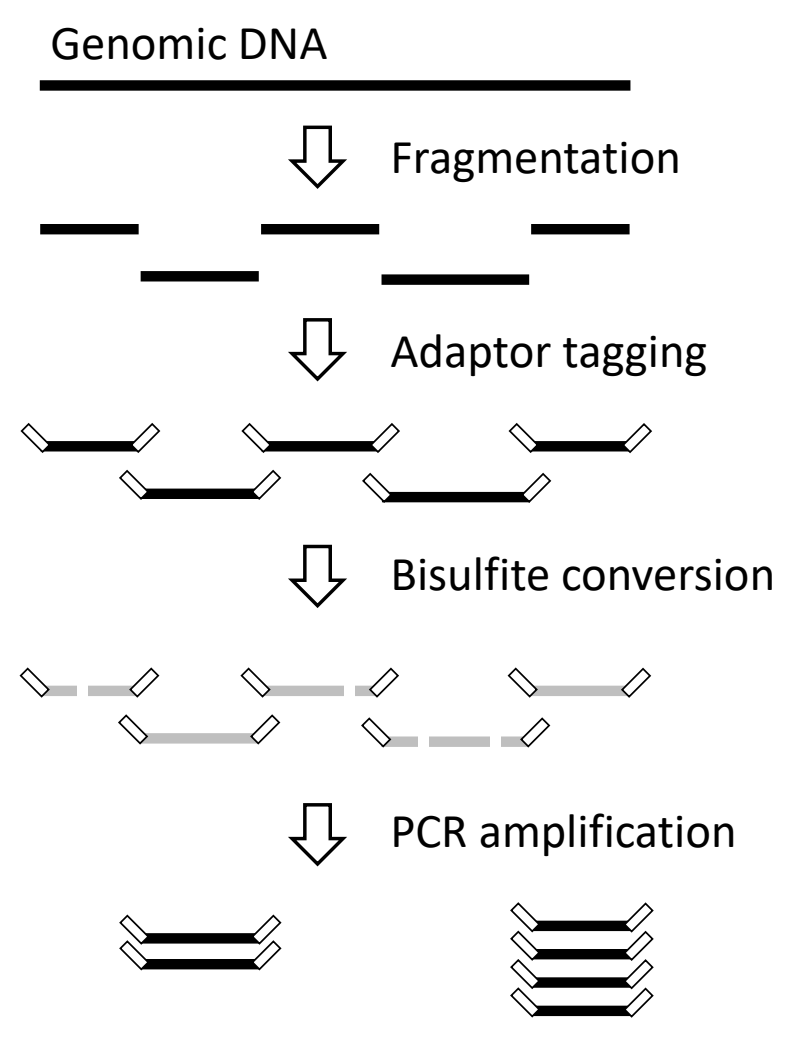

B

Genomic DNA
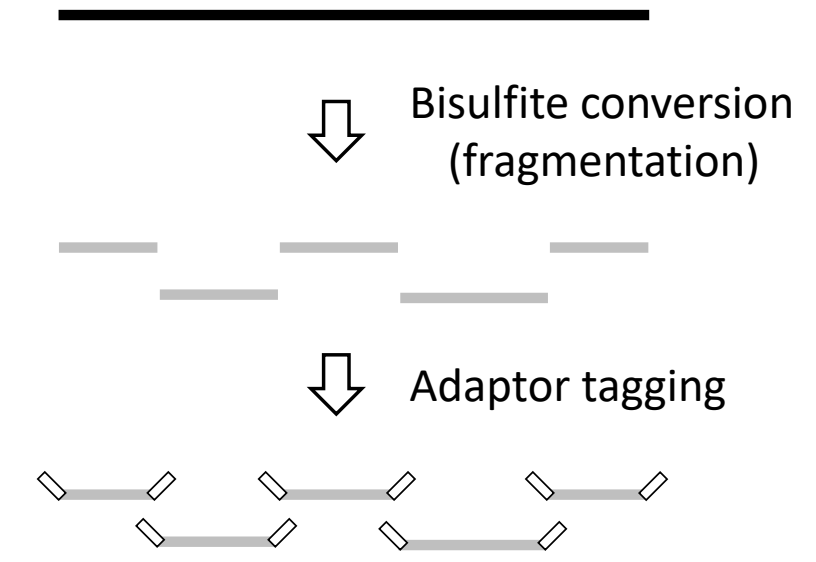

C

Genomic DNA

Љisulfite conversion

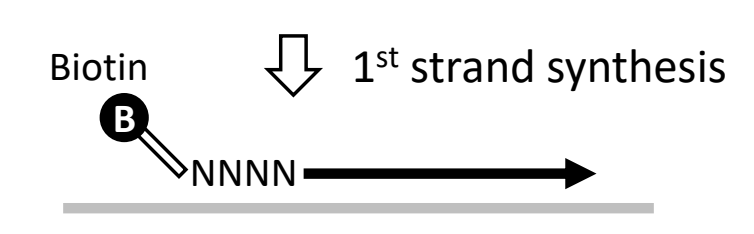

Streptavidin

beads

B

\& $2^{\text {nd }}$ strand synthesis

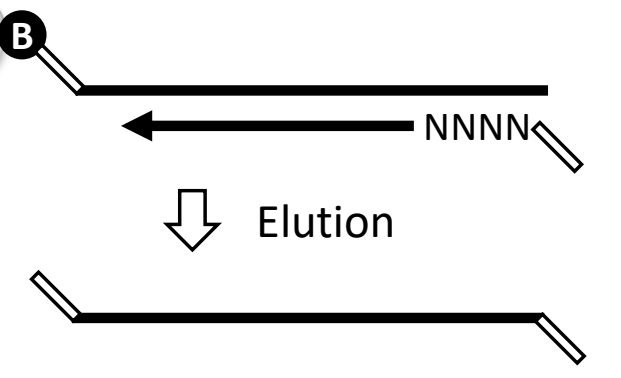



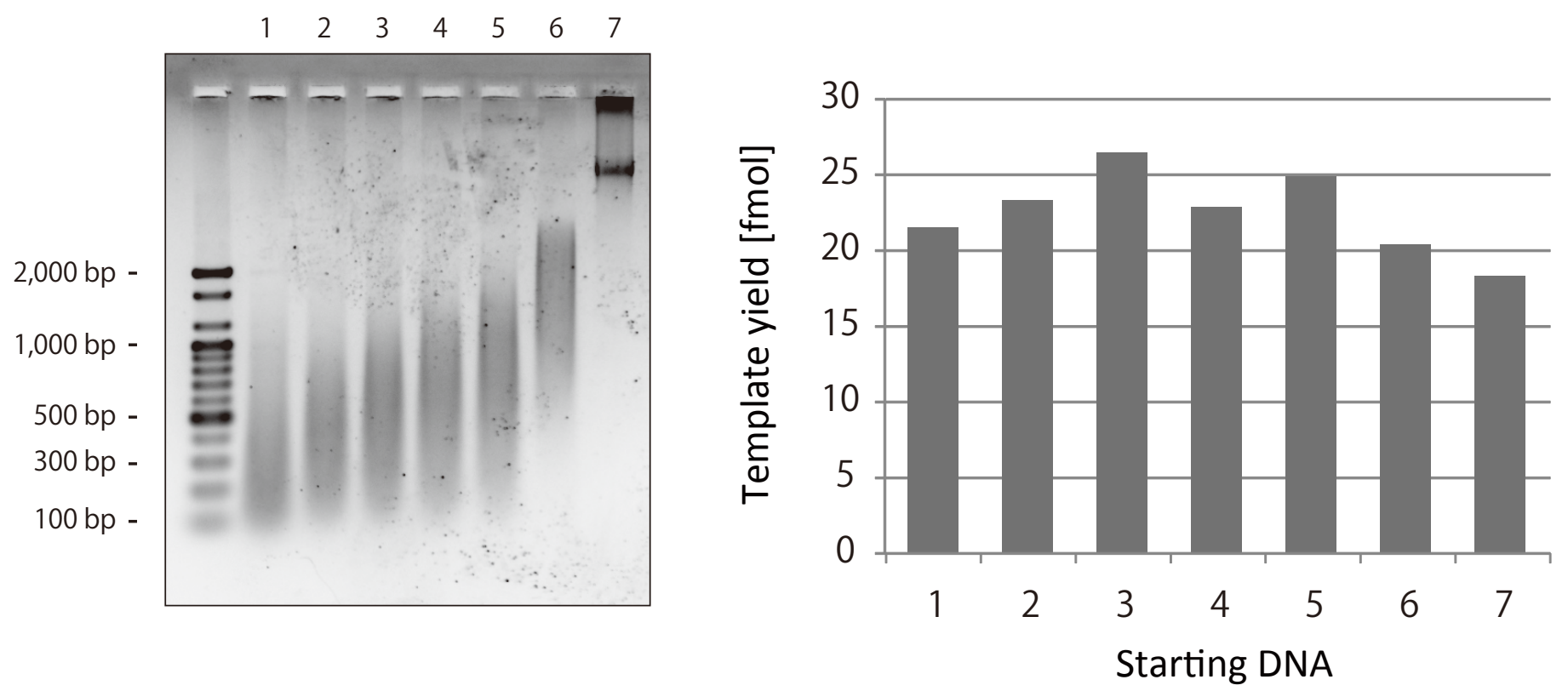

Figure 2 


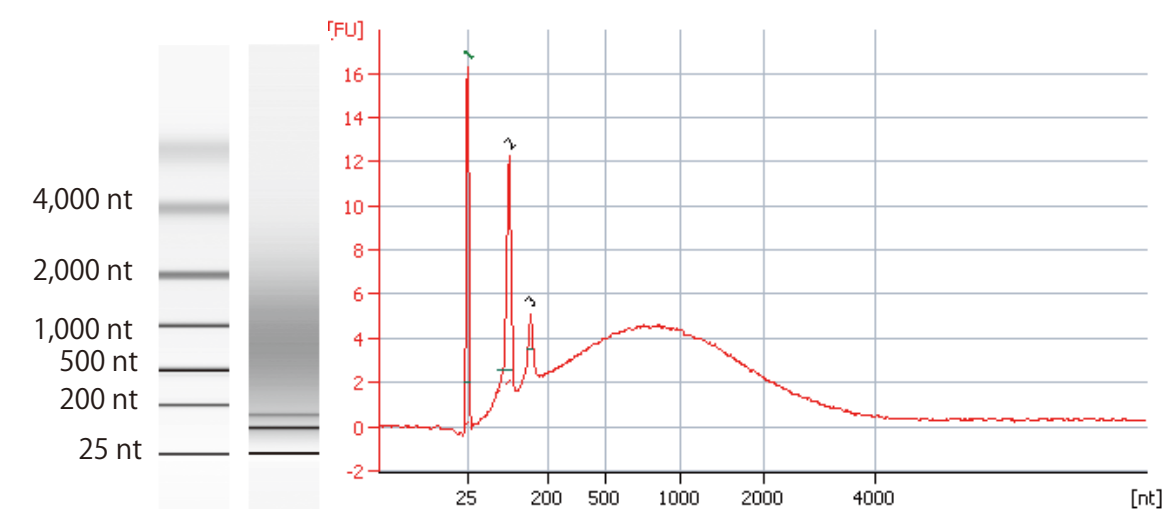

Fig 3 


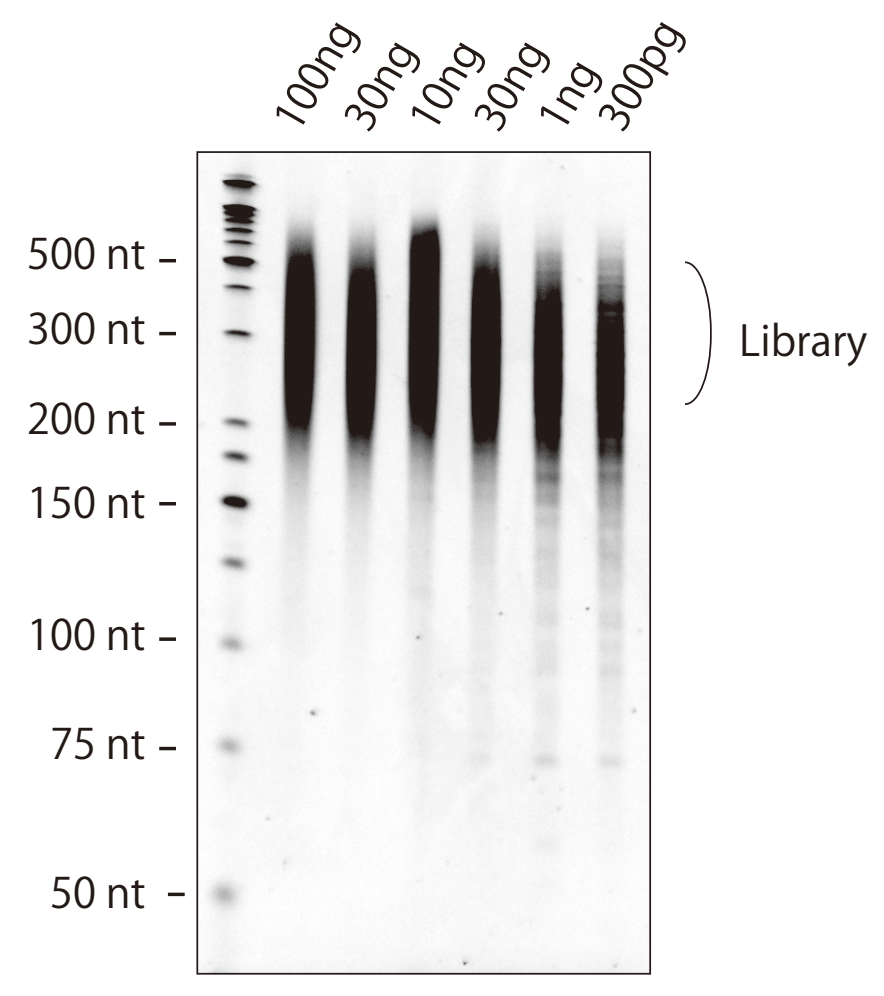

Fig 4 